\title{
Resources for Early Childhood Education (E.C.E)
}

\author{
Peace Ebele Ilechukwu Chukwbikem \\ Bluebell Montessori International School, \\ 10. L. A. Anga St., Off Peter Odili Rd., Port Harcourt, Nigeria
}

\begin{abstract}
The central theme of this paper is resources for early childhood educatio. The pape ohlio its issues such as purpose and benefits of ECE. It also discusses human, mater and fi ncial arces and gives detailed instructional resources for effective teaching at this leyero du ation. T enenefits of E.C.E. are that there is a positive relationship between E.C.E life perf monces the recist of this level of education. Good. ECE inculcates the spirit of enquiry and ativity thr exploration of nature and the local environment. It teaches them cooperation ean irit and go od habit. It also prepares them for primary education. The study also examine impon of play, things to look for in preschool curriculum which are human resources, mrerials and finano Zuality support system should include educational training for programme pers nel as well as ongoing technical assistance programme providers and individual care provider. Perse el who are y ell prepare through education, training and support are essential to achieving high qualit,
\end{abstract}

Keywords: E.C.E.; early childhood education; te 2 ducation

\section{INTRODUCTION}

Education begins $\mathrm{m}$ the mo $\mathrm{nt}$ a child is born and continues for the rest of his life. The learning capabili es hildren co ctinue for the rest of their lives but not at the intensity that is demonstrat $\rightarrow$ the chool years. Early childhood education refers to the formal teaching/learning of young c a cen by people outside the family (except when family member(s) i e pro sional teacher(s)) and in settings outside the home. It includes crèche nursery and ki. "arten ( deral Ministry of Education, 2004).

Bab es an oddlers ed positive early learning experiences to help their intellectual, social
ara oti personali $y$ child learns a language without conscious effort. He picks a language just by hearing it. Dehavioural theories of child development focus on how environmental interaction influences behavior and are based on the works of theorists such as John B. Watson and lvan Pavlon among others. These theories deal only with observable behaviors. Development is considered a reaction to rewards, punishment, stimuli and reinforcement. The areas of development according to Piaget (n.d.) are

Physical Development

Cognitive Development

Language Development and 


\section{Emotional Development}

- Bowbly (n.d.) believes that early relationships with caregivers play a major role in child development and continues to influence social relationships throughout life. Early childhood education focuses on child learning through play. It has been thought that the child learns more efficiently and gains more knowledge through play- based activities such as dramatic play, art and social games. Early childhood education is crucial to child development and should be entered into cautiously with the one that will benefit the child. Children must receive attention and affection to develop in a healthy manner. Many believe that education at preschool ages can signific ect a person's ability to deal successfully with later life.

Theory of Development Interaction

Ogbonnaya (2010) noted that early childhood education can be aced the of prominent educationists like Rousseau (1712-1788) and Pestalozzi (1, 1927). Ae lss added that one of the modern educationist Maduewesi (1977) holds th there sositive relationship between good early childhood education and re life $p_{0}$ ro ance of the recipient of this level of education. According to Piaget in lon ori (2009, there are four major stages of cognitive development:

- Sensor Motor: This stage occurs between birtb and two year of e.

- Preoperational: The second stage occurs betv en the ages of 2-7 years

- Concrete Operations: This development stag curs betw en the ages of 7 and 12

- Formal Operation: This stage of cognitive dev men takes place from ages 12 and beyond.

\section{THE PURPOSE}

Early childhood edy tion ation received by the child prior to primary education. An important aing to re nber when it comes to children and nature is to provide them with positive er $\rho \mathrm{c}$. ces of thy atural world around them. It allows the children to explore and discove for th selves the magnificence of nature by making sure they have adequate opport mitres to play yors with the guidance of the teachers and caregivers. With innate power f curio ity and ipagination they will find ways to connect with nature on their own by explo worms, lirt, leaves, sticks and rock. The mission of ECE is to provide leadershim and sort $t$ schools, organizations, educators, families and communities in impl men g progi nes that assist all children from birth through age 8 to become successful lif

\section{BENEF, IS OF EARLY CHILDHOOD EDUCATION}

- It is an undeniable fact that this aspect of education is the bedrock upon which all levels of education are anchored. The level of access a child has of early childhood education will definitely determine the ease with which the child can advance through other levels of education (World Bank 2000, Project Ministry of Health, 2004). 
- In addition, Highscope Perry preschool study $(2005$, p.2) stated that it inculcates in the child the spirit of enquiry and creativity through the exploration of nature and the local environment.

- It teaches cooperation and team spirit

- It teaches good habits.

- It prepares them for primary level education

- It provides adequate care and supervision of the children while their parents are at work.

- A study conducted in Ypsilanti Michigan, (1962-1967) found that adults who had preschool programme had higher earnings, were more likely to hold committed fewer crimes, and were more likely to have graduated from $y$ ilversity adults who did not have it. $(2005$, p. 3$)$

\section{THINGS TO LOOK FOR IN A PRESCHOOL CURRICULU}

\section{Curriculum}

Effective education requires both relevant curriculum ha ctitioners no understand and are able to implement the curriculum. Children der 4 raph during the early years physically, intellectually, emotionally and socially. mey are entitl 6 provisions which support and extend knowledge, understanding, sk ls, and confidence, and help them to overcome any disadvantage. Scientifically based, co prehensive furriculum to help you plan and implement a developmentally appropriate prog me that promotes children's socio emotional development and learning in th are area mathematics, science and social studies should be used.

- Teachers need to arrange onment that are symbol rich and interesting without being overwhelming to fants $\mathrm{d}$ toddl

- Well prepared teaches

- Small teacher - cbid ratios

- Stimulating an elopmenta appropriate curricula and setting

- To be eff ctre, an ean vriculum needs to be carefully structured. In that structure there ould orovision for the different starting points from which children develop thein in , build on what they already do, relevant and appropriate content matches the diffe levels of young children's needs, and planned purposeful activities which pr de opp ities for teaching and learning both indoors and outdoors. En ure that cyldren have access to various activities throughout the day. Look for assorted Irumo ocks and other construction materials, props for pretend play, picture books, p ts and other arts materials, and table toys such as matching games, peg boards and puz es. All the children should not necessarily be doing the same activities at the same time.

- Teachers work with individual children, small groups, and the whole group at different times, during the day. They do not spend all their time with the whole group.

- Classroom is decorated with children's original art work, their own writings with invented spelling, and stories dedicated by children to teachers. 
- Children learn numbers and alphabets in the context of their everyday experiences. The nature world of plant and animals and meaningful activities (like cooking, taking attendance or serving snacks) provide the basis for learning activities.

- Children work on project and have long periods of time (at least one hour) to play and explore. Work sheets are used little, if at all.

- Children have an opportunity to play outside every day. Outdoor play is never sacrificed for more instructional time.

- Teachers read books to children individually or in small groups throughout the day, not just at group story time.

- Curriculum is adopted for those who are ahead as well as for those who $\mathrm{n}$ ed addith help. Teachers recognize that children's different backgrounds and e ences me that they do not learn the same things at the same time, in the same y.

- Children and their parents look forward to school; parents feel ecure abou ning their children to the programme. Children are happy to attend, do $10.0 r$ resularly or complain of feeling sick.

\section{QUALITY STANDARD}

Quality support system includes education and raining for programme personnel as well as ongoing technical assistance to programme $\mathrm{p}$ viders and individual care providers. Research supports the widely held views that pers els wh, are well prepared through education, training and support are essentia achieving on quality. Most of these teachers do not have bachelor's degree. Another im 'orm amponent of quality support system is technical assistance - on site consultation an t dinin, that help staff at schools, as well as individual providers, to explore diff approa hes to working with children and address areas in which quality improvements re nec ed.

This type of assistance or tes for hands- on learning and problem solving in areas such as classrom moesig affective use of teaching materials, and working with children with unique ne. Technicar stance also serves to reduce the isolation experienced by smaller program es a individual providers and to assist personnel in continuously upgrading their $\mathrm{k}$. ledge an interested in p ogran ne expans, $\mathrm{n}$.

\section{Resources for $\mathrm{v}$ child ood education}

The Irpose arly childhood learning resources is to develop a set of high quality, in tive arly chilahood resource materials which nurture and support the development of early acy anu numeracy in children from birth to five years. These resources should be based on nd contemporary international research. These informative and practical materials should suit a range of early childhood settings and should provide examples of how parents, caregivers and practitioners can create stimulating environment for their children, thereby making use of the most critical period of rapid development in learning

Resources are the supplies that neede by an institution to improve their productivity Availability of resources (human, materials and finance) is critical to the successful implementation of any educational programme. This is because resources are needed to provide a conducive teaching and learning environment, purchase relevant instructional and learning materials and pay staff. The quantity and quality of resources available for any educational 
programme would therefore determine schools systems capacity for the implementation of the type of educational programme.

Resources are the material, staff and finance available to realize the goal of early childhood education. For any educational programme to achieve its goals, it must be supported with adequate resources. Adediji in Ukala (2012) defined educational resources as the sum of everything that goes into the educational system. This includes human, infrastructure and finance. Early childhood education is capital intensive. It is requires to be adequately equipped with vital input in order to achieve its goal. Physical facilities are land mark for school existence. As a matter of fact, preschool environments, classrooms, provisions of infractmaral materials are essential for meaningful interaction. The educational environm nit mu. conducive enough to facilitate children interaction with their environment th nables the construct experience.

The essential things are: Active play, After school and summer leo ning, Arts Cra is, Assessment \& Evaluation, Block play, Carpets and rugs, Childr 's bo s, Clà room Essentials, Curriculum, Differentiated Instruction, Dramatic Play ur c, Grea Gifts for kids, Home school, Infant and Toddler care, Language and Lite acy, Math atics Music and Video, Outdoor Learning, Parent Involvement, Play group a, file plan, Puzzles and games, Resource Books, Sand and Water, Social Emotio al, S 1 Studies, Science and Health, Special Needs Inclusions and Technology.

\section{HUMAN RESOURCES}

Qualified staff

All children are special so it stands to eas in the people who are responsible for educating them in their early years need to be retty special themselves. Not only must they have the ability to connect with anlm $\mathrm{n}$ and $\mathrm{u}$ derstand the world from their point of view, they must also be able to gi the cildren th attention they need to develop skills and worthwhile learning experi

Caregivers and tea er should ve knowledge of cultural supports for the language and literacy learning of th $c$ 'ren and silies they are serving. They need to have sufficient skills in guiding full attention to individual young children's language and literacy efforts. They need to o ole to draw out shy children while they help very talkative children begi to liste to others as will as to speak. They should be aware that children are not empty vessels. ar goal to bring out the hidden potentials in them. They are to bring the childrep the his te sible intellectual, social, moral and cultural levels.

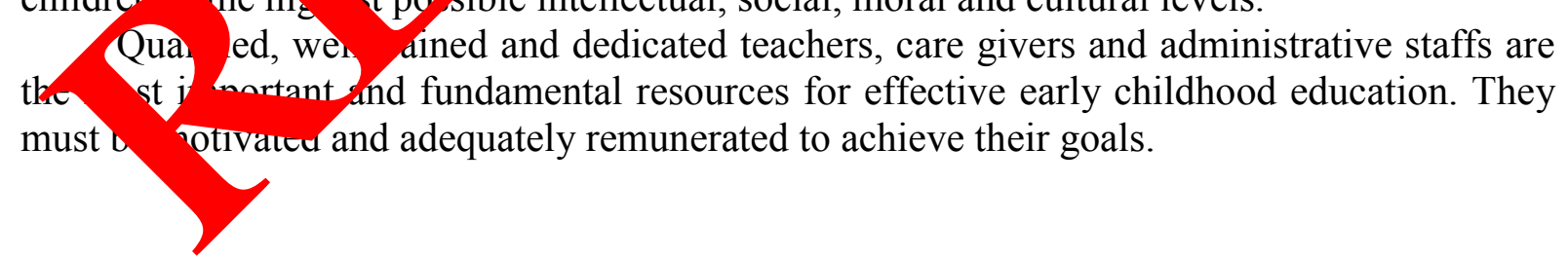

\section{MATERIAL RESOURCES}

Infrastructure is the most basic level of organizational structure in a complex system that serves as a foundation of the rest. 


\section{1. Infrastructure}

Infrastructure needed to support high quality early education services has three fundamental roles such as:

1. Establish and enforce programme and child outcome standards

2. Create and sustain a system to support elements of quality

3. Ensure quality through mechanisms for accountability and continuous quality improvement.

Gallagher and Clifford (2000) noted that states and communities lack adequate res to ensure that these activities are carried out effectively. The issue of quality in e? ly childı education is critical with the proliferation of private schools. There is great dea. evidence show that only those programmes that meet high standards produce sig lasti $\mathrm{g}$ benefits to the children they serve. They also observed that one of th mos riv ing characteristics of the current programmes for young children outside hom the assence of a comprehensive infrastructure. Demand for child care is ris be se of a ariety of factors, including economic conditions that have made it necess? for moth o o ork, woman attaining higher education with improve income, the numbe or ldren par cularly in child care has shadily grown. With the increasing important rol th chil re plays in our society, demand is also rising for evidence that these progranes provide $h$ /quality educational
experiences.

There should be established minimum criteria or safety an quality in early childhood education through its approval standards. While the ation of voluntary standards has been instrumental in raising the quality of pro mme, tho still significant gaps between standards for the best practice and the qualit on ices provided by most schools. Funding these is often viewed less essential than fund $g$ nat o ectly supports slots. Adequate indoor play space and workspace for tea ${ }^{2}$ and chi ren are essential. Standard classroom, Cross ventilated, well lit with inbuilt orage upboard with access windows. Walls painted in two or three bright colours, staff or and orderly. There should se abeà ful atmosphere

\section{2. Instructional ds} Importance of ray

Child elop experts agree that play is very important in learning and emotional development of childre It provides children with hand-on- experiences with water, sand, plaster a s a twigs. Play is multifaceted. However, it should be fun for the child, ofte man kills can e learned through play. Play helps children learn relationship and social skilh alues and ethics. Play should always be considered as an essential part of a child orly education.

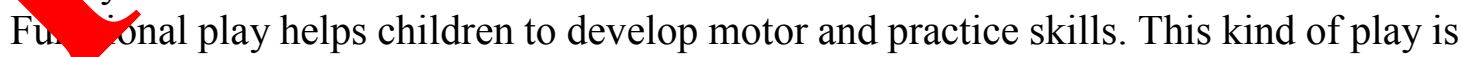
normally done with toys or objects that are stackable, can be filled with water or sand or playing outdoors. Water play and sand play are favourite among preschool children and a valuable teaching tool. This type of play can make up about $50 \%$ of the type of play toddlers to three years old children practice.

Constructive play is characterized by building or creating something. Toys that encourage this type of play are simple puzzles, building blocks, easy craft activities and puppets. Normally four to five years old children enjoy this type of play, but it continues to be enjoyable into the first and second grades of school. Hands and fingers are the best first art 
tools. Soon they will mange with paint brushes, wedges of sponge, wax, crayons, and hunky chalks. It is advised to avoid rushing a child into making something in particular. Letting them do what they want encourages individuality and decision making. Toddlers also enjoy dough because they can get hands and fingers in to it for poking, rolling and shaping. This type of play develops thinking and reasoning skills, problem solving and creativity.

Pretend play allows children to express themselves and events in their lives. It helps them process emotion and events in their lives. Allow them to pair materials stick and twigs, rock and pebbles, shells and leaves can be sorted, counted, used to build amazing structure, explore with magnifying glasses and use in art projects. Observe nature and ask them what thereae.

\section{Active Play}

Children develop large muscle coordination through active play som quipme stimulates gross motor activities that encourage the development of rhythm, nd- ye coordination and balance. A variety of active play toys like bean bag or tos g, nar nutes for lifting, mats for tumbling and soft foam balls for passing go ves aber $\mathrm{m} s$, safety trampoline bike pan, learn to craw tunnel folding bike.

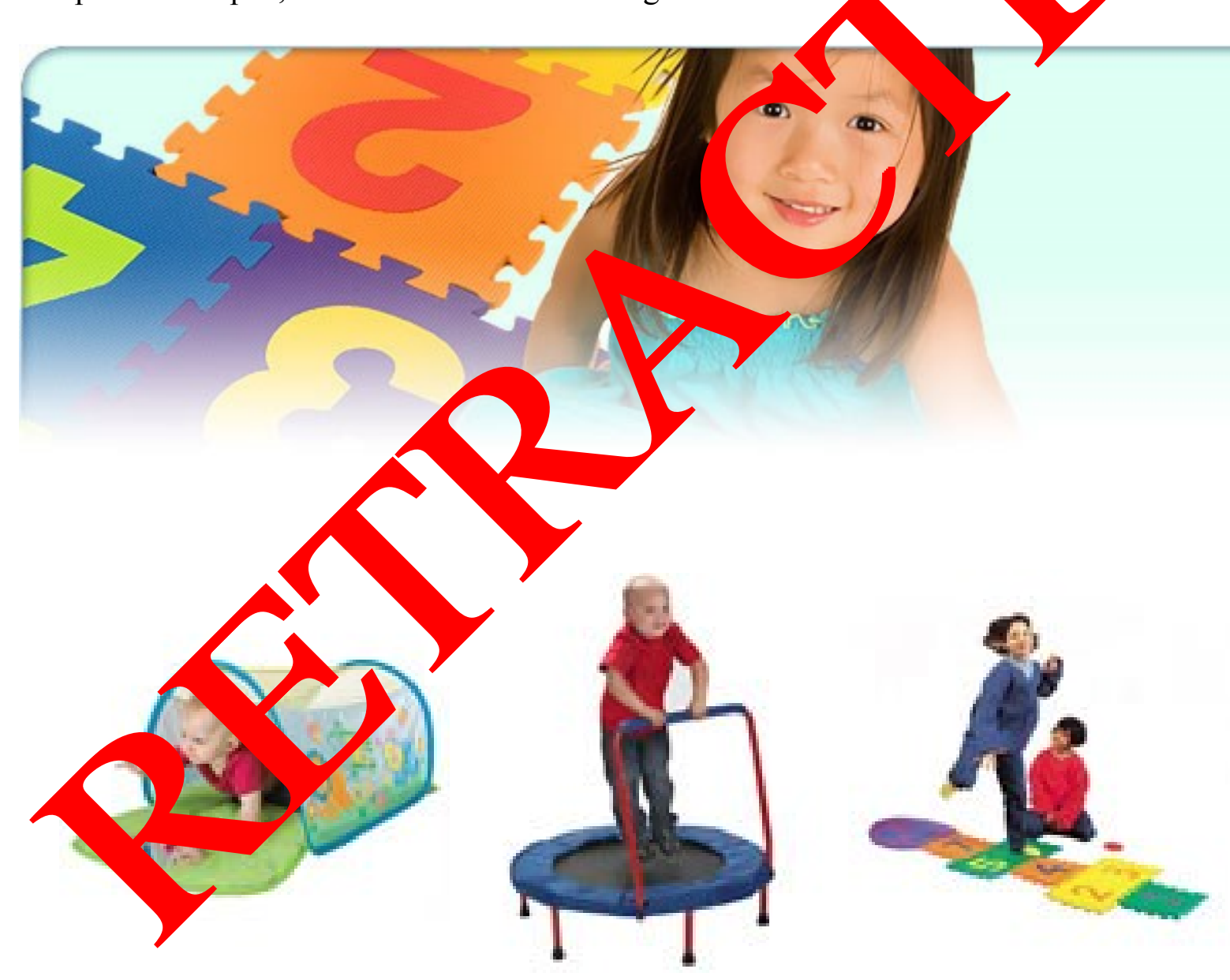

\section{After school and summer learning}

Curriculum based learning should not stop when the child is on vacation. Provide grade - appropriate learning materials in an after school and summer learning environment. It is an 
important element in helping pupils remember what they have learnt during the school day. Children need ongoing opportunities to learn and practice essential skills

i. Language Arts test prep in a flash Test Prep-Cards provides comprehensive practice for grade - level language art skills

ii. $\quad$ Shuffing into maths - Fun family

Maths games book games that help children learn basic counting numeration skills, addition etc.

iii. Electronic Learning Games becomes a word master with an electronic touch

iv. Monopoly Game: Trading game
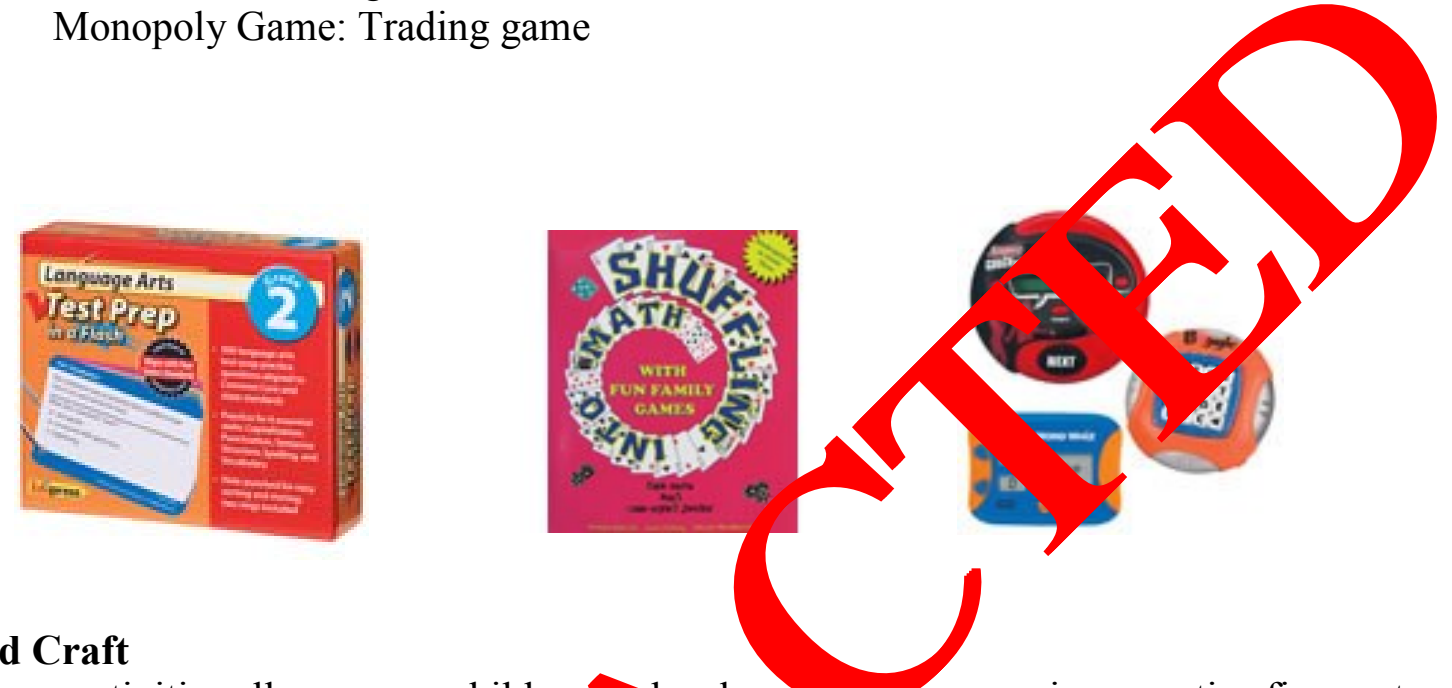

\section{Arts and Craft}

These activities allow young children expelop crumento practice fine motor skills, experiment with shapes, line and colou s.
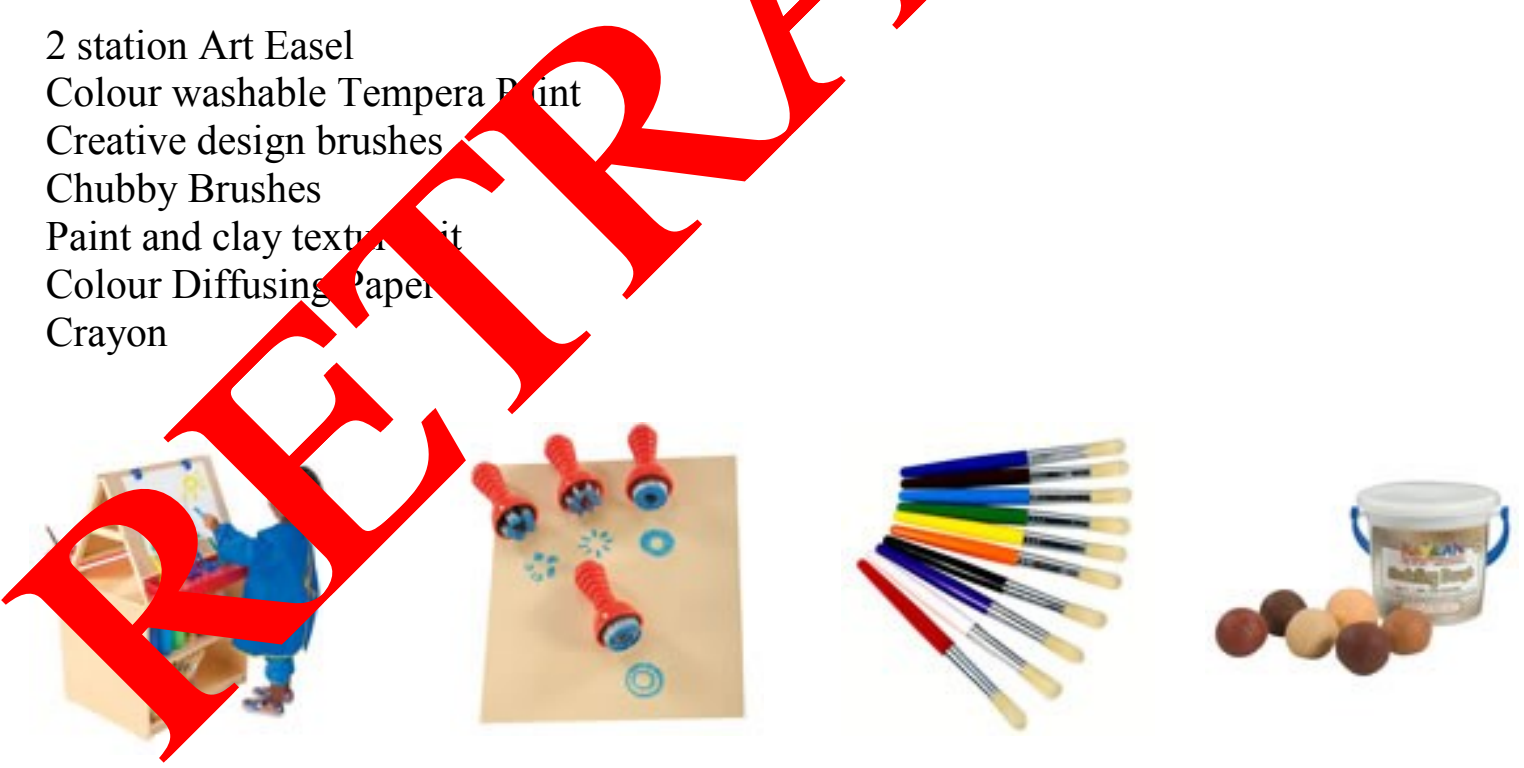

\section{Assessment and Evaluation}

Evaluation result helps professional and parents to plan learning experiences, evaluate programme goals and improve young children's social and emotional development. Early learning accomplishment profile kit measures development in six domains. 


\section{Block Play}

Block play offers a rich opportunity for early mathematics and science learning and the development of social, emotional language motor and cognitive skills.

\section{Totter Tower}

Building activity that helps children develop a sense of geometry, and hand-eye coordination e.g. Primary Toddler Blocks. Dado Planks
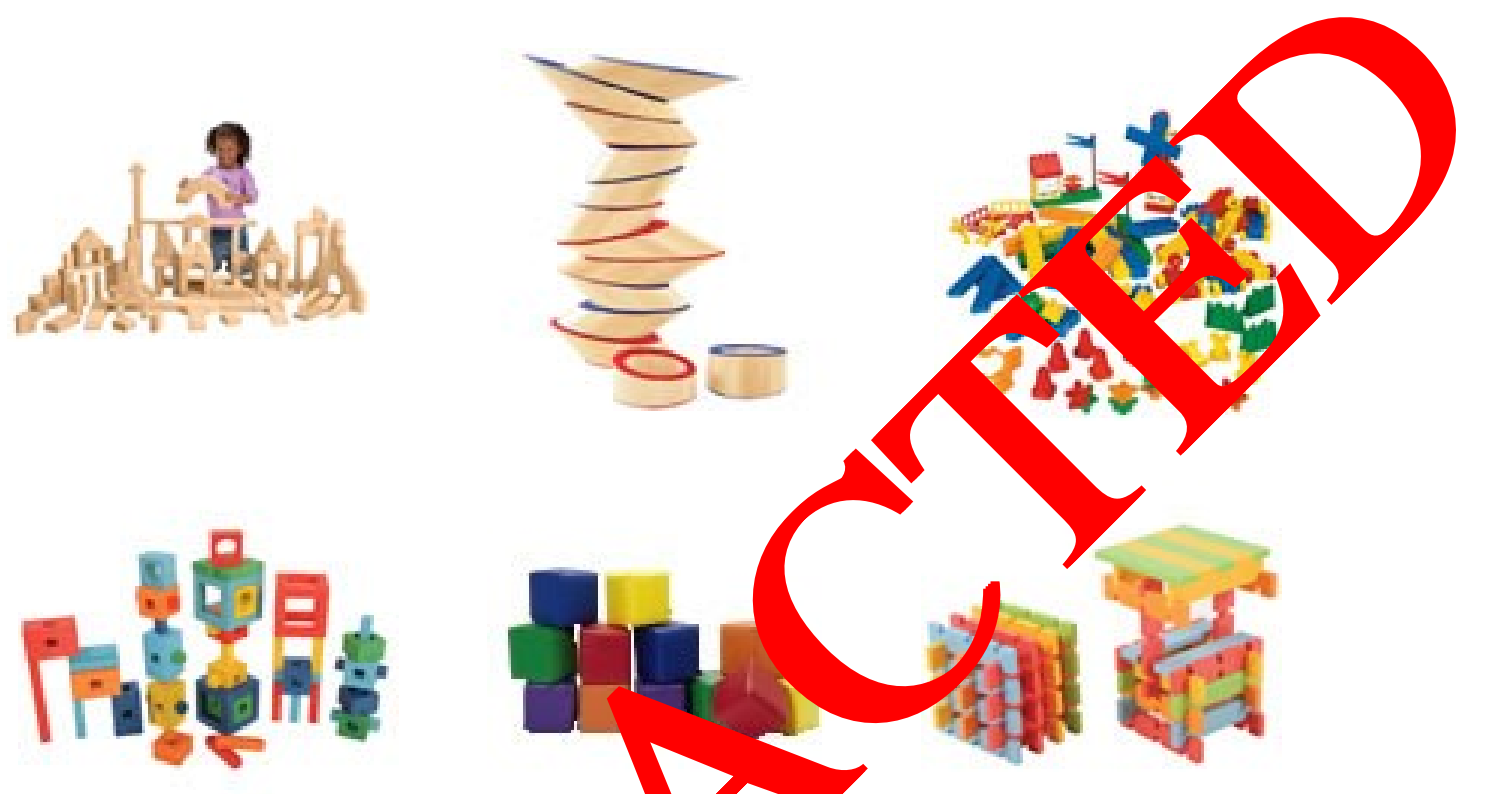

\section{Carpets and rugs}

Children need so ss in the bysical surrounding to relax and feel comfortable. Carpets and rugs in ght urs crea cozy classroom areas.

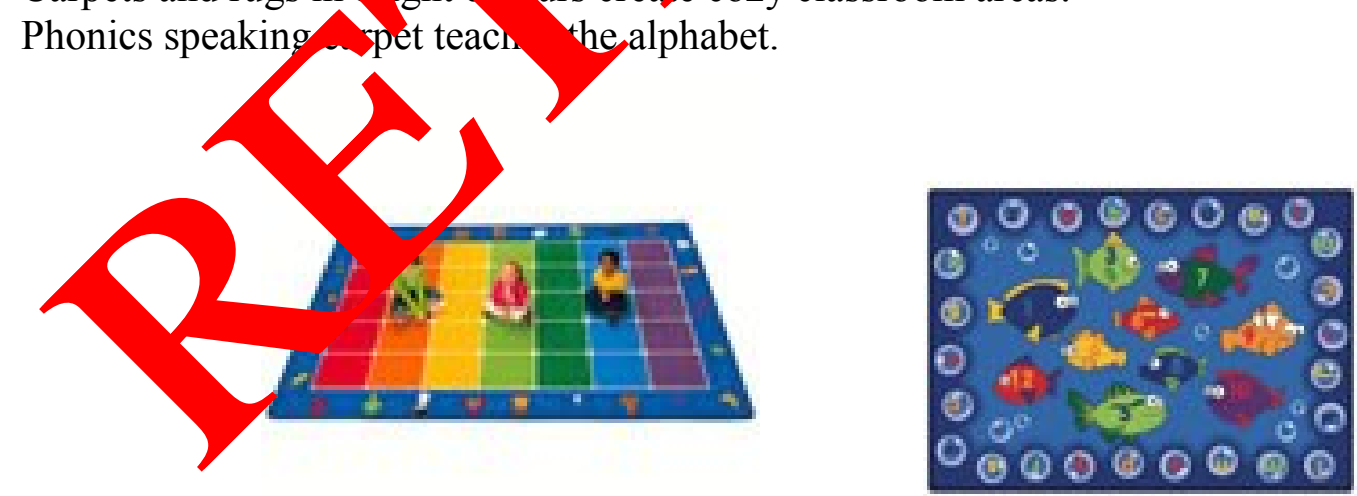

\section{Children's Books}

Help children develop a close and enjoyable relationship with books: factual book, fantasy, books about people of different races, cultures ages and abilities. Build your classroom library. 


\section{Classroom Essentials}

Create a bright, colourful print-rich environment for young learners Bulletin board displays

Decorative prints: art work, favourite characters

Scalloped edge bordettes for the edges of the board

Fanciful recycle bag

Classroom clock.
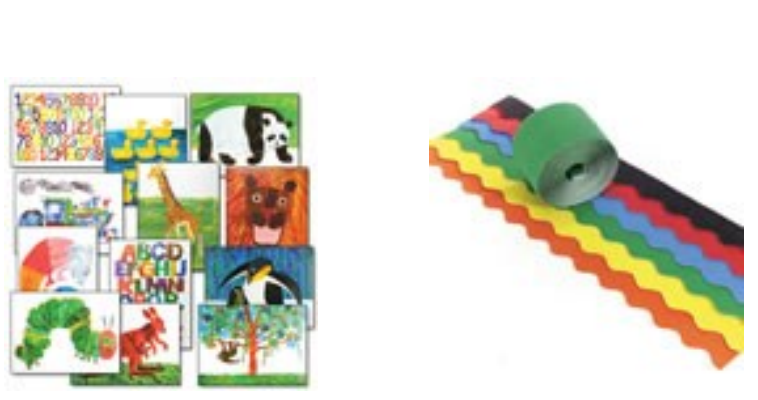

\section{Clearance}

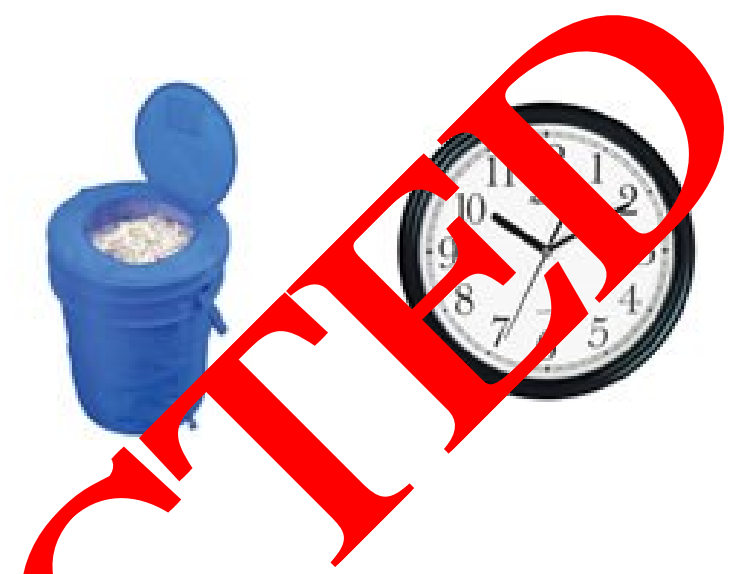

Nursery Rhymes Bulletin Board set

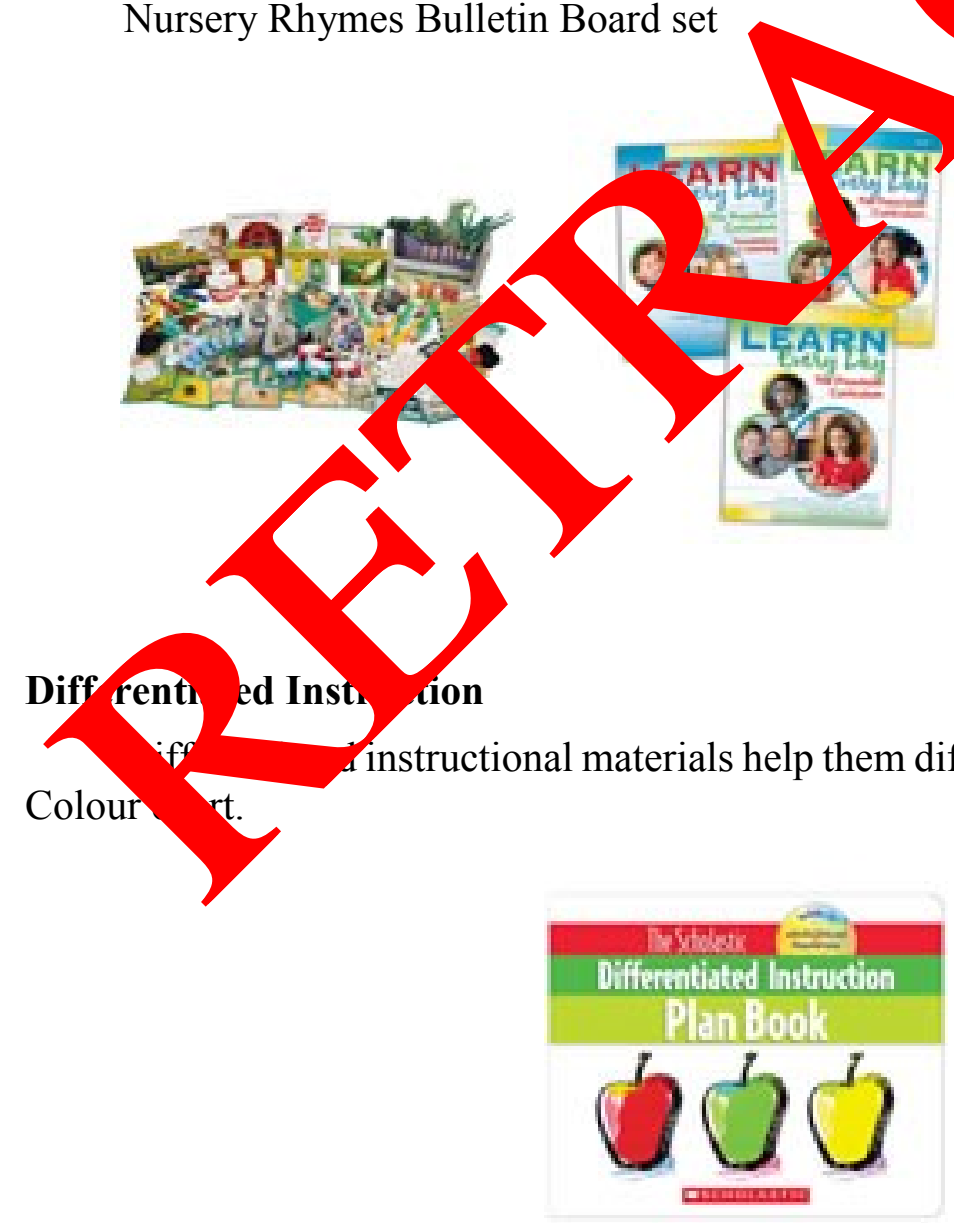




\section{Furniture}

Table, Chairs, Storage Units

Nature storage shelve

Rest mats

Standardcot
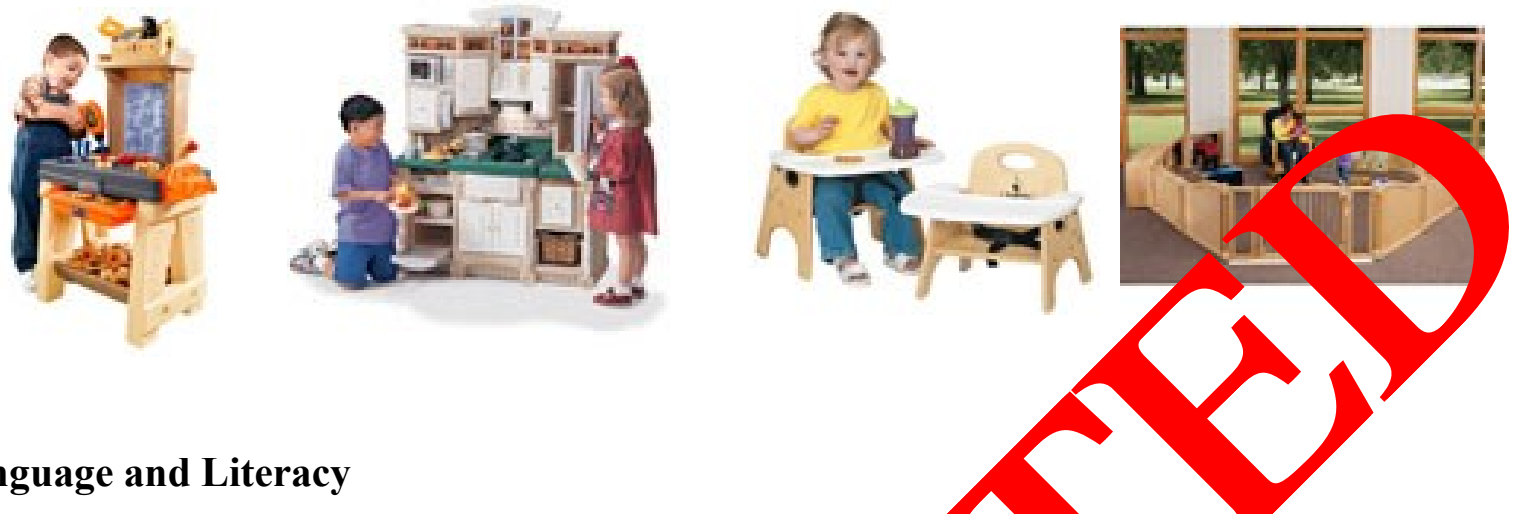

\section{Language and Literacy}

Teachers read books to children individually or in sn 1 gro througkout the day, not just at group story time. A-Z Pegboards set. Large letter a pegbo is a fun way to learn letter recognition and improve - eye coordination.

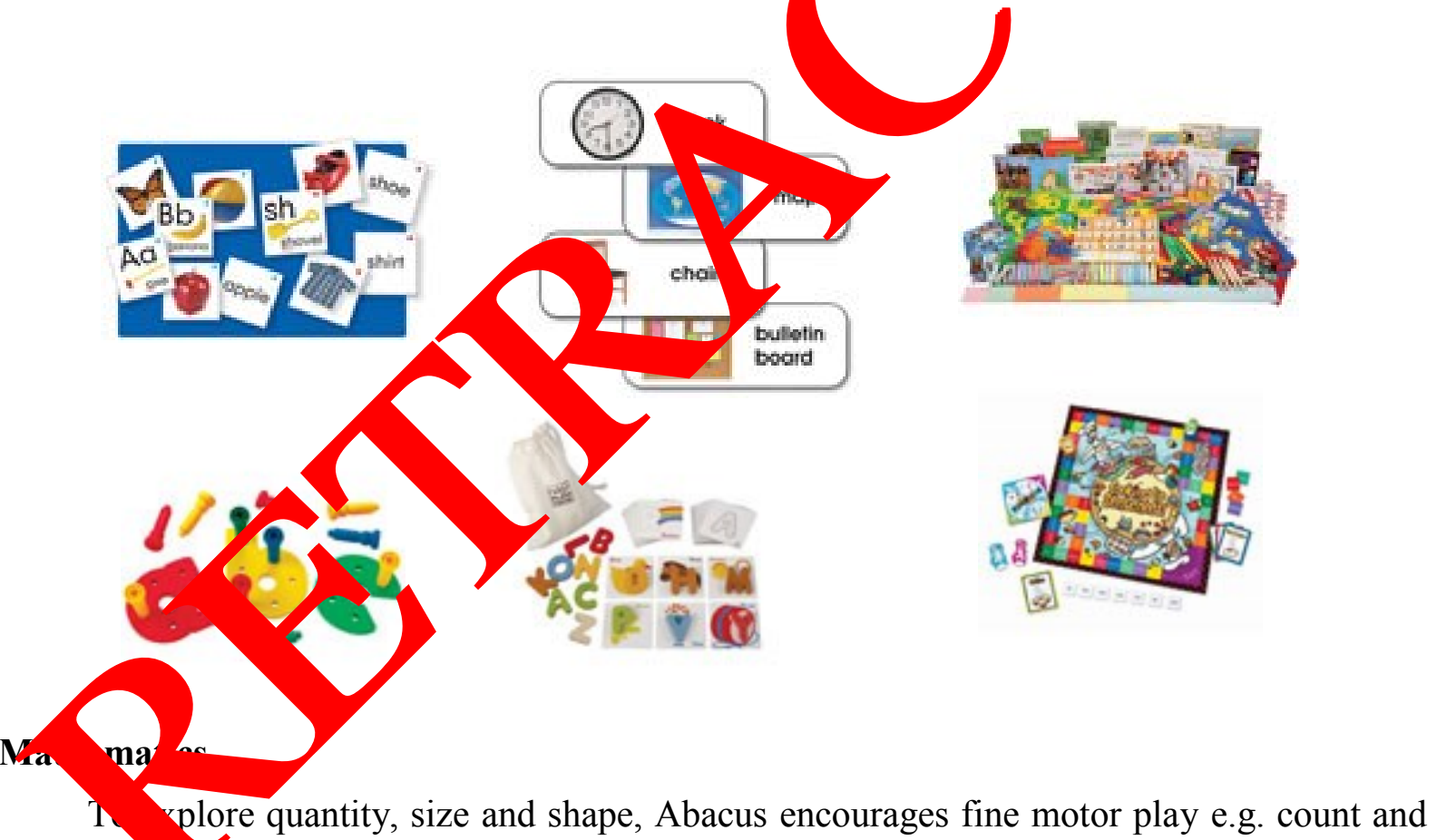
sort game.
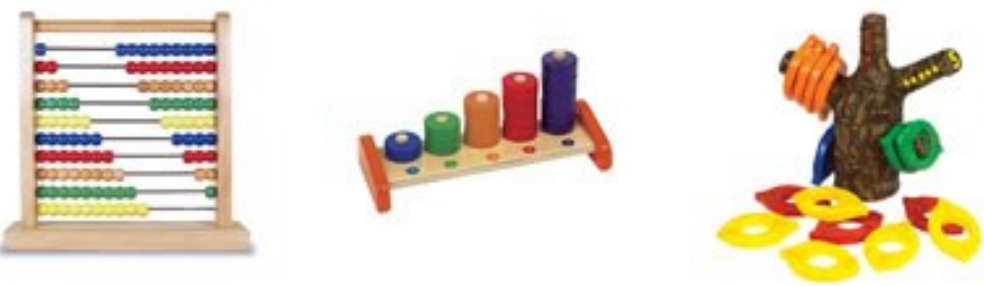


\section{Play Ground}

Wilkins (2002) identifies play ground, games and toys and other instructional materials as essential for successfully handling of children. Outdoor play maintains health and fitness and enhances learning and creativity. Children have an opportunity to play outside every day. Outdoor play is never sacrificed for more instructional time
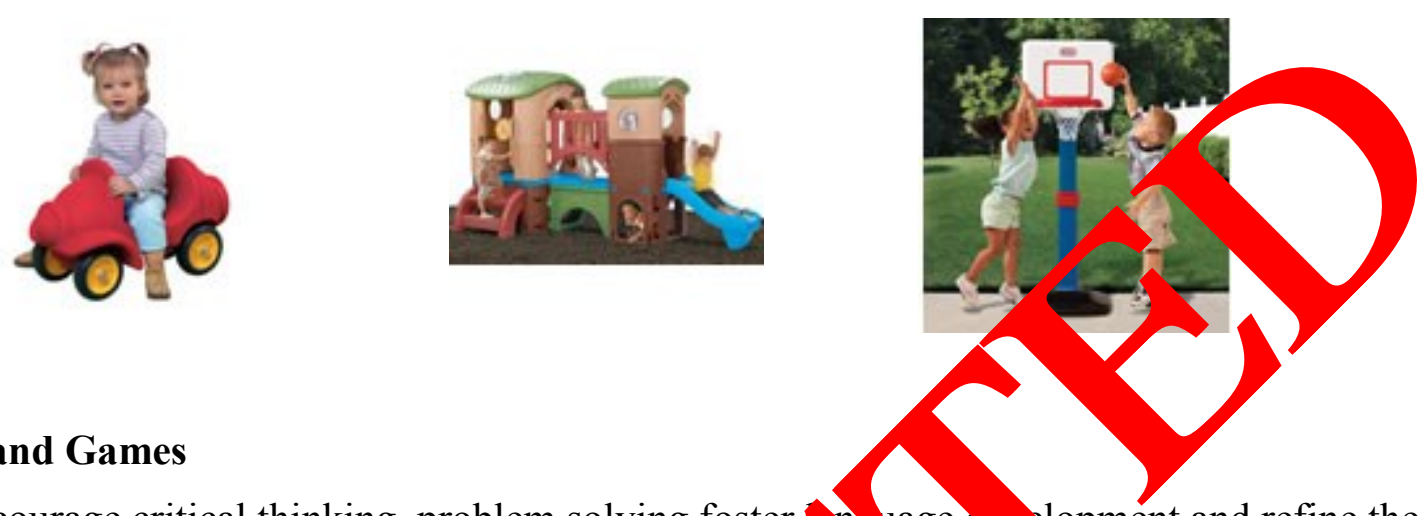

Encourage critical thinking, problem solving foster lopment and refine the basis for learning activities. Children work on project and have long 1 ods of time (at least one hour) to play and explore. Work sheets are used ttle, if at all.

\section{Bilingual Books}

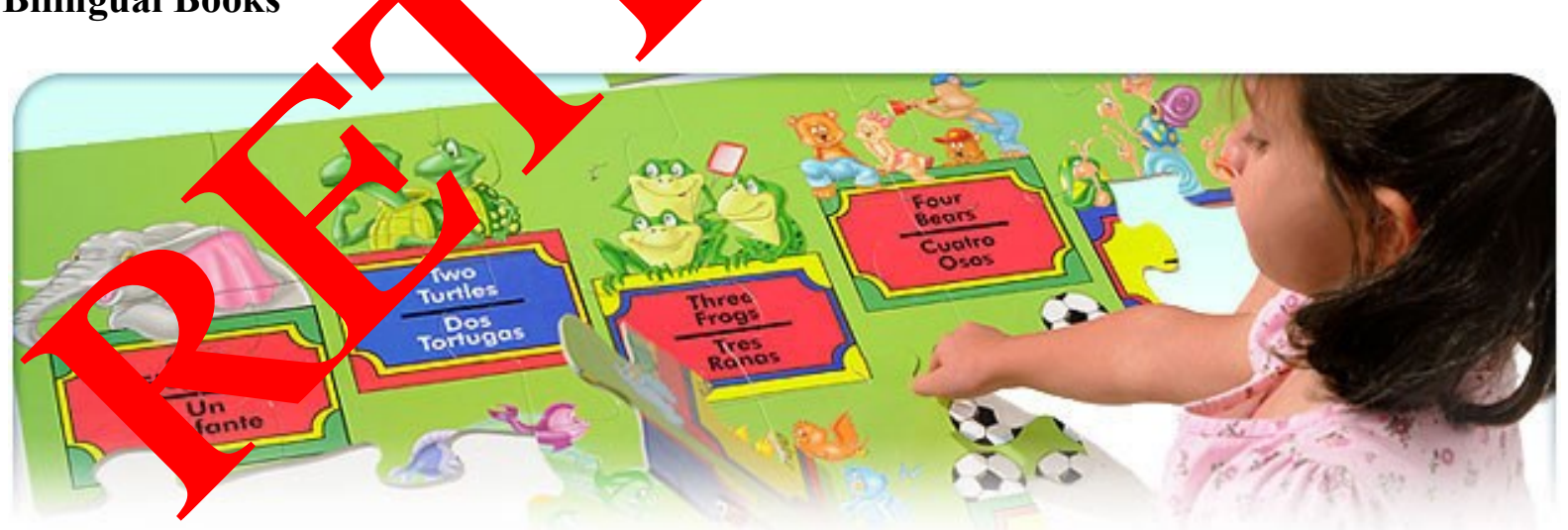

Curriculum is adopted for those who are ahead as well as for those who need additional help. Teachers recognize that children's different backgrounds and experiences mean that they do not learn the same things at the same time, in the same way. 


\section{Music and Video}
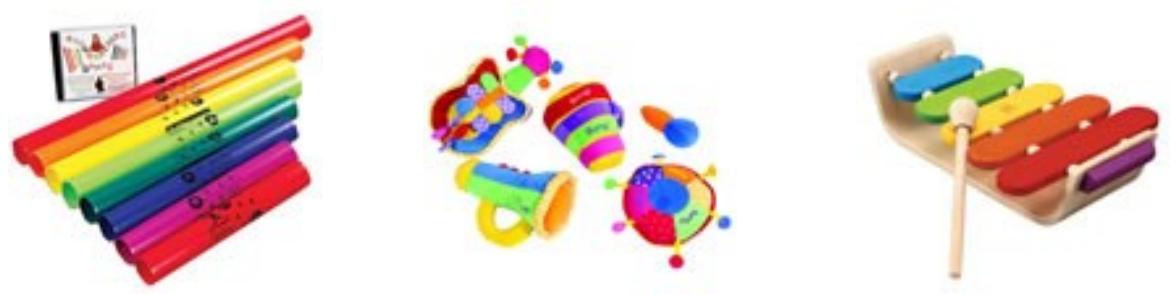

Tool peg puzzle Map jigsaw puzzle Bilingual number floor puzzle

\section{Resource Books}

Create a good professional library with a balanced collection of $\mathrm{ks}$ o vario y $y$ i early childhood subject by subject.

Curriculum and activity books

Books on child development theory and practice

\section{Sand and Water}

Children learn about measurement and natural cience as they experiment with sand and water. Toys that encourage children to dig, scoop, fi $\mathrm{d}$ pour er hance learning.

Transparent sand and water table

Dump truck

Sand exploration toddler set

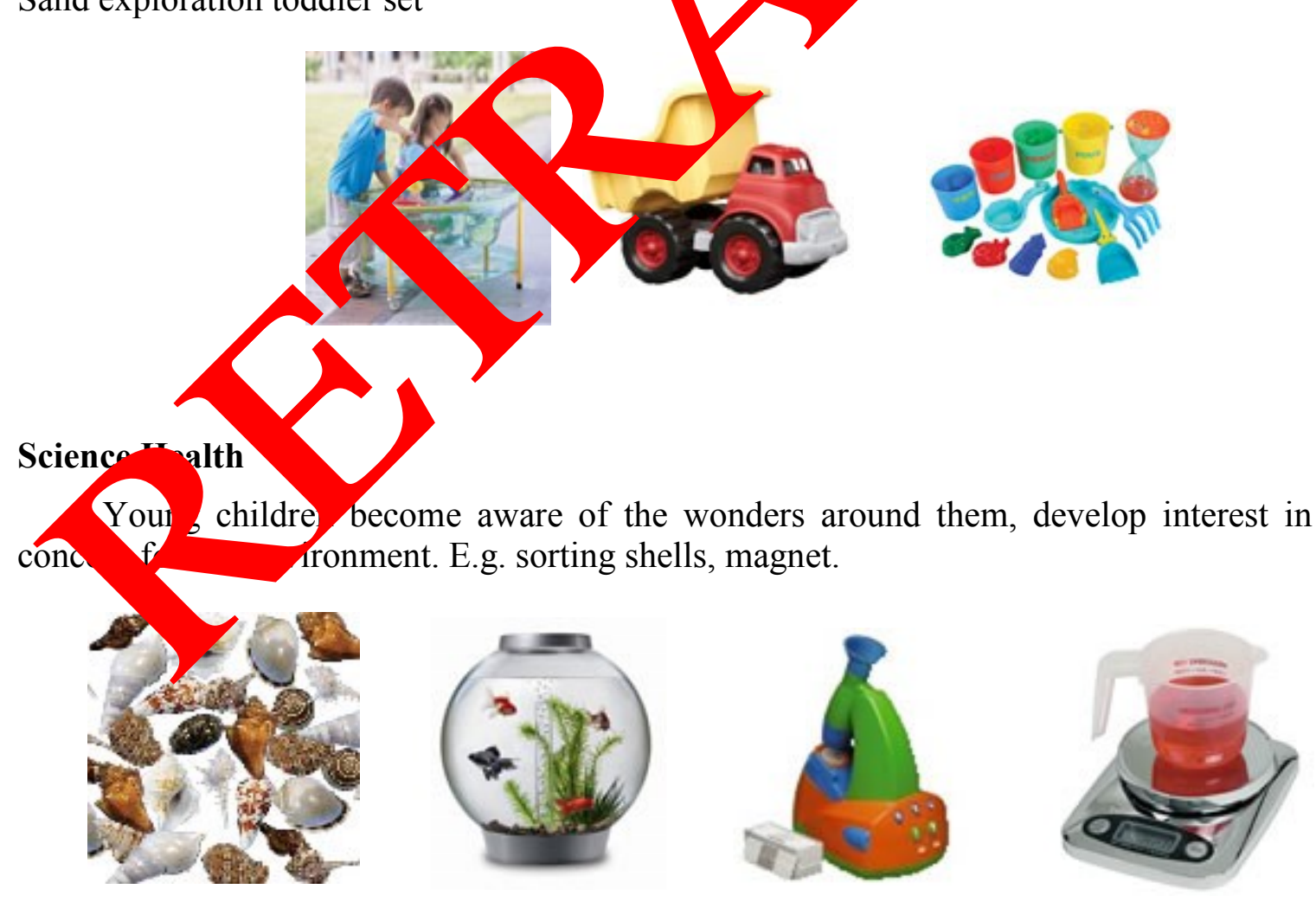




\section{Social Emotional}

Character education curriculum should be designed. Songs children tend to develop emotional attachment to what is familiar and comfortable to them. If they are to develop a sense of connectedness with the natural world, they need frequent positive experiences with the outdoors.

\section{Social studies}

Inflatable labeling globe
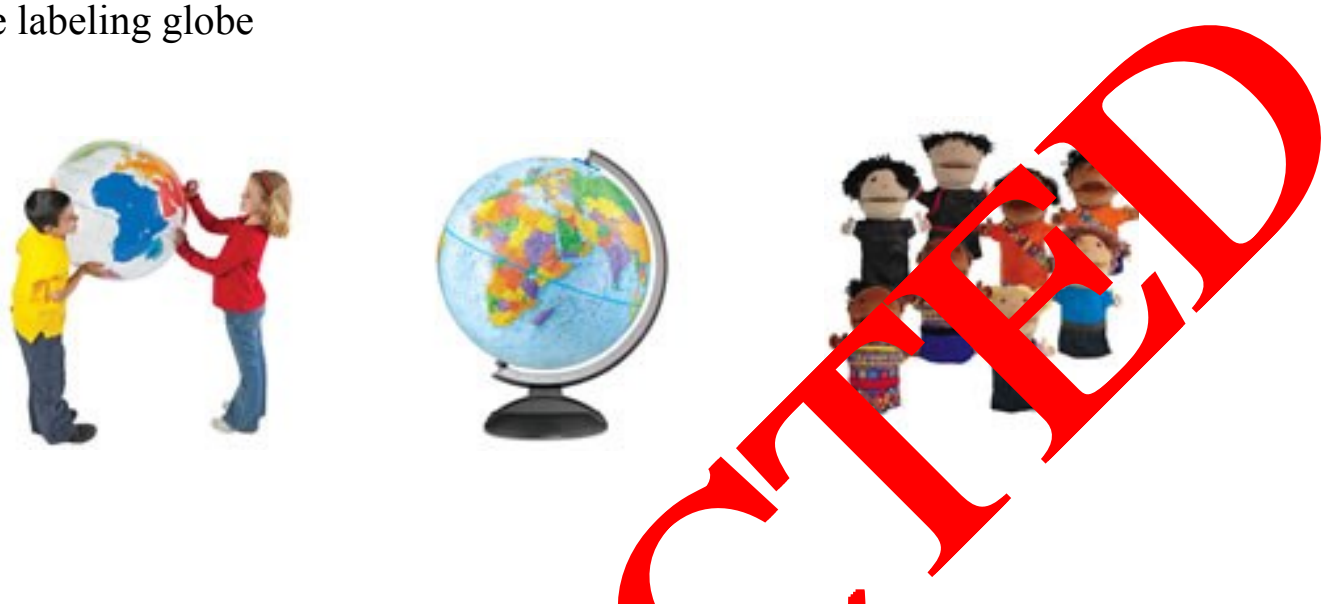

\section{Technology}

Kid safe computer Digital camera Computer m
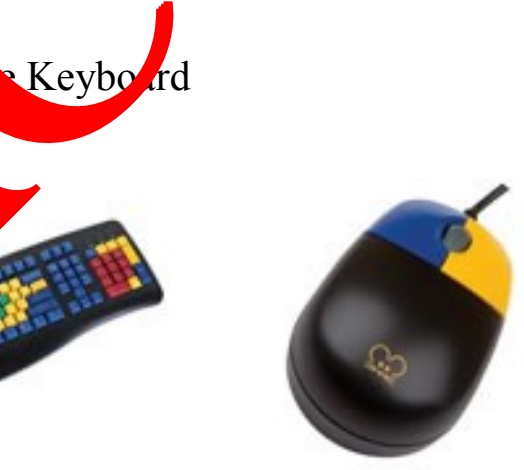

\section{Supplic}

Wate good source of water, treated borehole and water dispenser. Constant supply of water must be ensured.

Toilet: classroom toilets with wash hand basins of appropriate height. Separate for boys and girls. Sickbay and first aid box should be equipped. There should be a well trained nurse. 


\section{CONCLUSION}

The mission of ECE is to provide leadership and support to schools, organizations, educators, families and communities in implementing programmes that assist all children from birth through age 8 to become successful lifelong learners. It is an undeniable fact that this aspect of education is the bedrock upon which all levels of education are anchored. The level of access a child has of early childhood education will definitely determine the ease with which the child can advance through other levels of education. Quality support system includes education and training for programme personnel as well as ongoing technical assictance to programme providers and individual care providers are imperative to ensure qua 1 ly den $\mathrm{Y}$. Personnel who are well prepared through education, training and support essential achieving high quality

\section{References}

[1] Agabi O. C. (2002). Finance and Economics of public International Centre for Education services

[2] Ahmed A., Journal of Education 6 (2010) 2

[3] Bowbly J. (n.d). The Father of Attachment Theo www/child levelopmentMedia. Com $>$ Home $>$ Articles. Retrieved from internet.

[4] Callaghan J. F, Clark L. H. (1977). Inno tion and is in Education. New York: Macmillan Publishing co.

[5] Kaplan early learning facilities (2013), http//www.kaplan.org/comm 13/sprit v/early. Retrieved from internet

[6] Federal Republic of Nigen o04 official gazette on UBE Act 2004. Lagos: Federal Govt. press

[7] Gallagher J., Cliff (2002). D y childhood Research and Practice. $\mathrm{http} / / \mathrm{ecrp}$ ujuc \& $\mathrm{u} / \mathrm{V}$. Gallagher.htm. Retrieved from internet

[8] Highscope erry Preschool dy (2005). Lifetime effects: the Highscope Perry Prescho tudy ough age 40 www.high e.org/ce tent.asp\%3fon . Retrieved from internet

[9] Maum wu S. A A.) (2006). Administration of Universal Basic Education: The bo e facts. 9 werri: Springfield published Ltd. Children interest and concerns: a study nety schl pupils

[10] Ma wesi E. (1977). Children's Interest and concerns: A study of Anambra elementary schoo pupils. Unpublished Thesis (Ph. D), Michigan State University. Department of Education.

[11] May P. (2011). PDT topic childcare and early Education quality. http // cedac.org /files/ infrastructure report. . Retrieved from internet

[12] Montessori classroom activities for early years -training workbook (2009). Lagos: Chelis book concept 
[13] Ogbonnaya N. O. (2010). Principles and application of educational policies in Nigeria. Nsukka: University Trust Publishers, Nsukka.

[14] Piaget, J. (n.d.). The Pedagogy. www/pedagogiaemfoco.pro.pe09.htn. Retrieved from internet

[15] Ukala C. C. (2012). Resource capacity for the implementation of early childhood Education in Public and private school in Rivers State. Unpublished Ph.D. Dissertation, Faculty of Education, University of Port Harcourt.

[16] Wilkins R. (2002). Linking resources conceptual and practical problems: Edy management and administration (Q 263-211 x). London: Sage publishers

[17] World Bank, (2000). September. Showcasing early child care and develop Innovation and application in Africa. International conference on eo nychild development. (ECCD). At Uganda, International conference centy Kam la Ug (1999) Washing D.C. World Bank.

[18] Donovan A. McFarlane, International Letters of Social an Humanis Ccie ces 4 (2013) 35-44.

[19] Seyed Mohammad Marandi, Hossein Pirnajmuddin ternation Letters of Social and Humanistic Sciences 1 (2014) 14-27.

[20] Ardian Shingjergji, Besa Shingjergji, Internati al Letters of Social and Humanistic Sciences 2 (2014) 56-66.

[21] Abbas Taghipour Javan, Salar Framar hmad Aou, rahime Hassan Nattaj, International Letters of Social and Hum this ances 6 (2014) 9-21.

[22] Ardian Shingjergji, International Letters Social and Humanistic Sciences 6 (2014) 74-80.

[23] Tomáš Hes, Anna Polerna vá Lumatignal Leters of Social and Humanistic Sciences 2 (2013) 18-31.

[24] Mohsen Mehrar a umeh ziry, International Letters of Social and Humanistic Sciences $2(20, \sqrt{32-1}$

[25] Taiwo Adewale Muritala, nail O. Fasanya, International Letters of Social and Huma is Scimes? (2013) 39-50.

[26] Borayski . Intern ional Letters of Social and Humanistic Sciences 3 (2013) 46-53.

[27 Boro ski A., IJ rnational Letters of Social and Humanistic Sciences 3 (2013) 69-74.

[28] av, Nishant Dabhade, International Letters of Social and Humanistic Sc. es 4 (2013) 49-69.

[29] Boroy ski A., International Letters of Social and Humanistic Sciences 4 (2013) 70-74.

[30] Paul Bukuluki, International Letters of Social and Humanistic Sciences 5 (2013) 27-44.

[31] Mohsen Mehrara, Maysam Musai, International Letters of Social and Humanistic Sciences 5 (2013) 55-62.

[32] Debiprasad Mukherjee, International Letters of Social and Humanistic Sciences 6 (2013) 41-48. 
[33] Tomáš Hes, Alena Neradová, Karel Srnec, International Letters of Social and Humanistic Sciences 7 (2013) 55-75.

[34] Kinga Dziwańska, International Letters of Social and Humanistic Sciences 7 (2013) 96-112.

[35] Borowski A., International Letters of Social and Humanistic Sciences 7 (2013) 113-118.

[36] Mohsen Mehrara, Maysam Musai, International Letters of Social and Humanistic Sciences 8 (2013) 1-7.

[37] Tittenbrun J., International Letters of Social and Humanistic Sciences 11

[38] Mohsen Mehrara, Hamid Abrishami, Mostafa Boroujli, Mahan Amin, In Letters of Social and Humanistic Sciences 11 (2013) 76-83.

[39] Borowski A., International Letters of Social and Humanistic Scie ces 1 (1)2013) 100-105.

[40] Sele Sylvester Ebisin, International Letters of Social and H manistic $1-9$.

[41] Tittenbrun J., International Letters of Social and Hy ristic S. ces 2 (2014) 20-40.

[42] Borowski A., International Letters of Social an Humanistic Sciè ces 2 (2014) 110-121.

[43] Pawa Tersoo, International Letters of Social an Humanistid Sciences 3 (2014) 26-36.

[44] Rabi'u Muhammad Ishaq, International Letters o, sial hd Humanistic Sciences 3 (2014) 37-44.

[45] Adoga James Ada, International Letters f Sctay hd Humanistic Sciences 3 (2014) 45-52.

[46] Bahram Meihami, Husse Meih hi, Inter ational Letters of Social and Humanistic Sciences 3 (2014) 80-

[47] Onyike Maggaret Meterna of Social and Humanistic Sciences 4 (2014) 31-39.

[48] Uloma Cha ity Oguzor, rovational Letters of Social and Humanistic Sciences 4 (2014) $9-104$.

[59] Okezie A gba, Al Odii, A. C. Njoku, International Letters of Social and $H$ nistic ince 5 (2014) 21-34.

$[50$ Qkez A. Ihug a, Bankoli Bankong, N. C. Ebomuche, International Letters of Social Mic Sciences 5 (2014) 92-113. 